\title{
The demersal fish composition and catch per unit effort of mini bottom trawl at the coast of Demak Regency Central Java
}

\author{
Naliyana Fitriya $^{1}$, Nahlah Alfiatuunisa ${ }^{1}$, Suwarman Partsuwiryo $^{1}$, Eko Setyobudi ${ }^{1}$ \\ ${ }^{1}$ Fisheries Department, Faculty of Agriculture, Universitas Gadjah Mada, Indonesia
}

\begin{abstract}
Demak is a coastal area on the North Coast of Java with a large enough potential for demersal fish resources. This research aimed to determine the composition, the length and weight distribution, and catch per unit effort (CPUE) of demersal fish caught using mini bottom trawl at the north coast of Demak Regency. The research was carried out in OctoberDecember 2020 by observation of ten trips of mini bottom trawl fishing. Each fish captured was then grouped by type, identified, and measured its length and weight. The result showed that 38 species consist of 31 fishes, four mollusks, and three crustaceans. The fish captured dominated by pony fish (Leiognathus equulus) as much as $31.23 \%$ and largehead hairtail (Trichiurus lepturus) of $23.52 \%$. The catch per unit effort (CPUE) average of mini bottom trawl was $44.77 \mathrm{~kg} /$ trip. Mainly fish (more than 95\%) caught in small size compared it's the maximum attainable length (L-max), with all the weight ranges from 0.3 to $520 \mathrm{~g}$ and more than $98 \%$ sized $0.3-80 \mathrm{~g}$. Mini bottom trawl catches many types of fish and small size; therefore, mini bottom trawl is classified as a type of fishing gear with a very low selectivity level.
\end{abstract}

\section{Introduction}

Fisheries are renewable resources; however, the exploitation should be conducted responsibly based on their carrying capacity. Fish capture using non-eco-friendly fishing gear has shown a significant effect on the pressure of fisheries resources. Some fishing gear damages fish resources and destroys the habitats and ecosystems in which they live. Continuously fisheries exploitation without regard to its carrying capacity and fish regeneration will lead to the depletion of the potential of fisheries resources [1].

The North Coast of Java (FMA 712) is one of the waters that have experienced excessive demersal fish resources. According to the Ministerial Decree of Maritime and Fisheries Number 50 of 2017, the potential source of demersal fish in the Java Sea is 657,525 tons/year. It has been exploited as much as 0.83 with a number of catches allowed (JTB) by 526,020 tons/year. This value indicates that this area has been fully exploited; therefore, fish capture activities should be controlled appropriately.

Demak is one of the regencies located on the North Coast of Java, which has enormous fisheries resources, both demersal fish and pelagic fish [2]). As at other regencies, fishermen 
faced several problems that are their fish catch activities depend on the availability of marine resources and environmental/seas conditions [3]. Most of the traditional fishing communities used mini bottom trawl to maximize their catch production.

The mini bottom trawl is a type of fishing gear that is operated by boat or ship. This tool is installed with ballast to sink the net and otter board to open wide of the net; subsequently, the net is pulled using a boat and catch all types of fish [4]. The mini bottom trawl is a modified type of trawl bag, and it is classified as a trawl net (mini otter trawl). The mini trawl has resulted in decreasing in fisheries resources and a threat to environmental sustainability. Based on the KEPPRES Republic of Indonesia No.39 of 1980 and Ministerial Decree of Maritime and Fisheries Republic of Indonesia No. 2 of 2015, the mini bottom trawl is prohibited from operating in the Fisheries Management Area the Republic of Indonesia. The mini bottom trawl caught in all sizes of fishes and other types of resources. Besides that, the operation of this fishing gear could impact fish habitat such as coral reefs damage. Shrimp is the main target of mini bottom trawl, whereas the bycatch is the demersal, pelagic, shell, and other small fish. The bycatch has a lower economic value, and there some are not even utilized. Due to the low level of selectivity and catching small fish, the operation of mini bottom trawl can disrupt the ecosystem's regeneration.

Excessive fisheries effort will pressure the fish resources and impact the environmental balance. This research aimed to determine the catch composition and possible impact of using mini bottom trawl. This information was expected to manage the fish capture activities to ensure the fisheries resources sustainability at the Coast of Demak Regency.

\section{Material and Method}

\subsection{Material}

The tools used in this study were mini bottom trawl, fishing boat, a ruler with an accuracy of $0.1 \mathrm{~cm}$, analytical scales with an accuracy of $1 \mathrm{~g}$, fish identification book, camera, and Mc. Excel. The material used was the samples of demersal fish and the catches of the mini bottom trawl. The boat used by fishermen is $5 \mathrm{GT}$, and the engine power is $23 \mathrm{PK}$, as much as $3-4$ engines. The boat's length is 7.75 meters, the width is 3 meters, and the depth is 0.9 meters. The mini bottom trawl design showed in Figure 1.

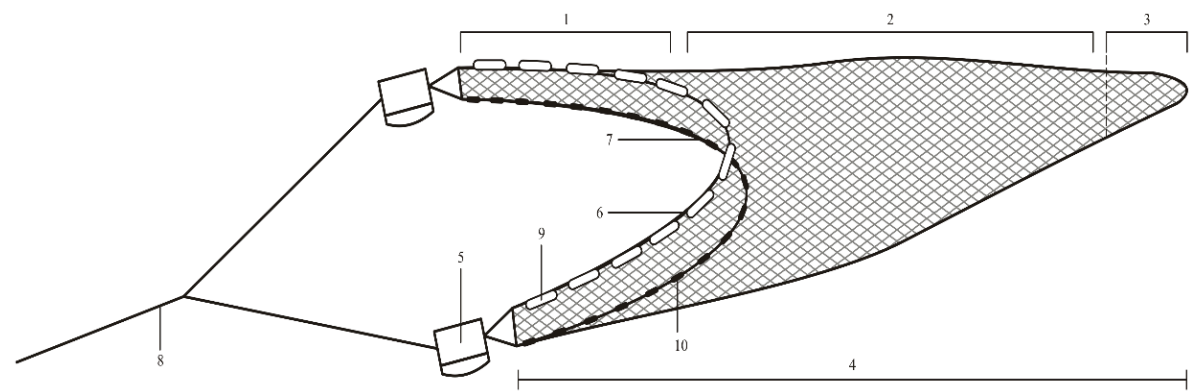

Fig. 1. The design of mini bottom trawl. 

1.Wing
6. Head rope
2. Body
7. Ground rope
3. Cod-end
8. Sweeps
4. Total length of net
9. Buoy
5. Otter board
10. Ballast

Table 1. Construction of mini bottom trawl.

\begin{tabular}{|c|l|c|}
\hline No & Components & Size \\
\hline 1. & Wing & $10 \mathrm{~m}$ \\
\hline 2. & Body & $14 \mathrm{~m}$ \\
\hline 3. & Cod-end & $2 \mathrm{~m}$ \\
\hline 4. & Total length of net & $23 \mathrm{~m}$ \\
\hline 5. & Otter board & $0.85 \times 0.45 \mathrm{~m}$ \\
\hline 6. & Head rope & $9 \mathrm{~m}$ \\
\hline 7. & Ground rope & $11.5 \mathrm{~m}$ \\
\hline 8. & Sweeps & $125 \mathrm{~m}$ \\
\hline 9. & Mesh size of cod-end & $0.5-1 \mathrm{inch}$ \\
\hline 10. & Mesh size of wing & $30-40$ inch \\
\hline
\end{tabular}

\subsection{Method}

The research was conducted in the Northern Coast of Java Sea, Purworejo Village, Bonang District, Demak Regency, Central Java from October to December 2020. The research location of the mini bottom trawl showed in Figure 2.

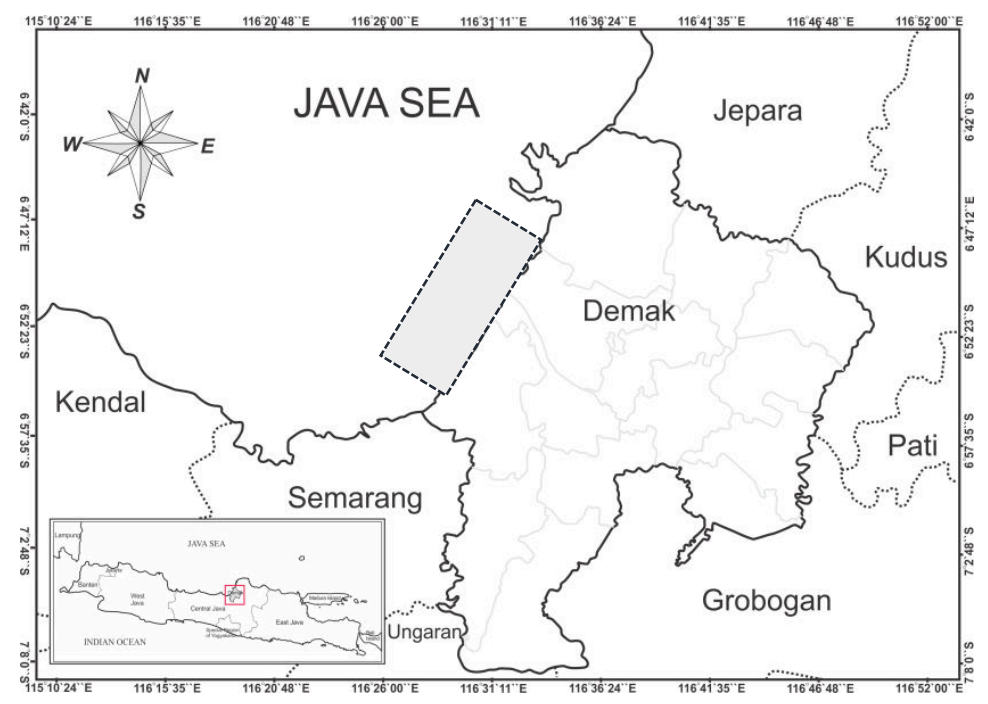

Fig. 2. The predicted fishing ground of mini bottom trawl at the Coast of Demak Regency

\subsubsection{Data Collection Method}

One fisherman who used mini bottom trawl as fishing gear to catch fish at Coast of Demak was selected as a sample. Data collection was conducted at ten trips; in every trip, fishermen carry out the setting and hauling for three times with 2.5 hours per setting-hauling. The data 
collection, i.e., construction of mini bottom trawl, types of the primary target and bycatch fish, the composition of demersal fish, distribution of length, and the weight of demersal fish.

\subsubsection{Data Analysis Method}

The catches were identified to determine the common name, scientific name, FAO name, and habitat classification (pelagic and demersal fish species) using fish identification books [5] and Fishbase. All the data was then processed using Microsoft Excel software to determine the composition of the catch by comparing the total weight of each type of fish.

Catch Per Unit Effort analysis was processed using Microsoft Excel software. Catch Per Unit Effort (CPUE) was used to determine the ratio of catch per unit effort. Catch Per Unit Effort is calculated using the following formula:

$$
P(\%)=\frac{N i}{N} \times 100 \%
$$

Explanation:

$\mathrm{P} \quad$ : Percentage of one type of fish caught (\%)

$\mathrm{Ni} \quad$ : Weight of one type of fish $(\mathrm{kg})$

$\mathrm{N} \quad$ : Total weight of all types of fish $(\mathrm{kg})$

\section{Result}

The catches of mini bottom trawl consisted of 38 species, i.e., 31 demersal and pelagic fish species, four mollusks, and three crustaceans. The proportion of catches using mini bottom trawl at the Coast of Demak Regency showed in Figure 3.

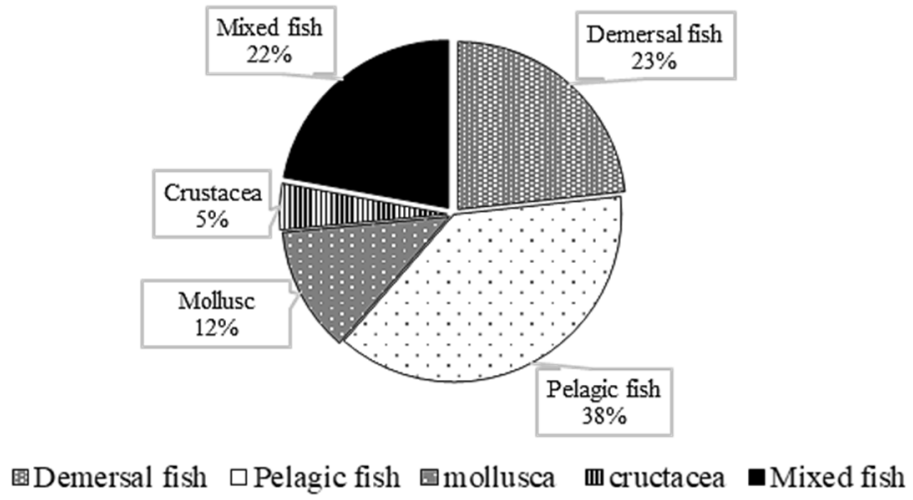

Fig. 3. The fishes caught by mini bottom trawl at the Coast of Demak Regency.

Figure 3 shows that the catches of mini bottom trawl consist of pelagic fish (39\%), demersal fish $(23 \%)$, and mixed fish $(22 \%)$. The mixed fish group is pelagic and demersal fish that are of small size and have low economic value. Besides of fish group, there are types of mollusk (12\%) and crustacea (4\%). The composition of target and non-target species caught by mini bottom trawl is shown in Figure 4. 


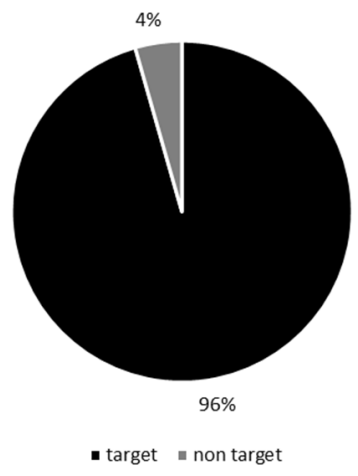

Fig. 4. The composition of target and non-target species caught by mini bottom trawl.

Figure 4 shows that the catches of mini bottom trawl are dominated by the non-target species as much as $96 \%$ and target species of $4 \%$. The catch composition and distribution of weight and length of demersal fish showed in Table 2.

Table 2. The catch composition and distribution of weight and length of demersal fish.

\begin{tabular}{|l|l|c|c|c|c|c|}
\hline \multicolumn{1}{|c|}{ Scientific name } & \multicolumn{1}{|c|}{ Common name } & $\%$ & $\begin{array}{c}\bar{x} \text { Weight } \\
(\mathrm{gr})\end{array}$ & $\begin{array}{c}\bar{x} \\
\text { Lenght } \\
(\mathrm{cm})\end{array}$ & $\begin{array}{c}\text { Lmax } \\
(\mathrm{cm})\end{array}$ & Ratio \\
\hline Trichiurus lepturus & Largehead Hairtail & 23.52 & 26.2 & 33 & 234 & 0.14 \\
\hline $\begin{array}{l}\text { Lagochepalus } \\
\text { spadiceus }\end{array}$ & $\begin{array}{l}\text { Half-smooth Golden } \\
\text { pufferfish }\end{array}$ & 7.98 & 50.4 & 12.65 & 37.4 & 0.33 \\
\hline $\begin{array}{l}\text { Saurida } \\
\text { micropectoralis }\end{array}$ & Shortfin lizardfish & 4.86 & 29 & 15.3 & 38 & 0.4 \\
\hline Leiognathus equulus & Pony fish & 31.23 & 9,75 & 7.05 & 28 & 0.25 \\
\hline Terapon jarbua & Jarbua terapon & 1.98 & 52.47 & 13.8 & 36 & 0.38 \\
\hline Priacanthus spp. & Bullseye/ bigeye & 1.88 & 19.82 & 9.9 & 45 & 0.22 \\
\hline Pampus argenteus & Silver Pomfret & 1.01 & 164.3 & 19.7 & 60 & 0.32 \\
\hline Upeneus sulphureus & Sulphur goatfish & 1.58 & 8.46 & 8.3 & 23 & 0.36 \\
\hline $\begin{array}{l}\text { Nemipterus } \\
\text { japonicus }\end{array}$ & Threadfin bream & 6.62 & 26.2 & 11.95 & 32 & 0.37 \\
\hline Mene maculata & Moonfish & 0.62 & 21.12 & 10.5 & 30 & 0.35 \\
\hline Abalistes stellaris & Triggerfish & 1.16 & 40.16 & 14.56 & 60 & 0.24 \\
\hline $\begin{array}{l}\text { Pomadasys } \\
\text { maculatus }\end{array}$ & Sadle gunt & 0.15 & 49 & 14.9 & 59.3 & 0.25 \\
\hline $\begin{array}{l}\text { Synaptura } \\
\text { commersonnii }\end{array}$ & Commerson's sole & 1.55 & 32.1 & 17.5 & 32 & 0.54 \\
\hline Drepane punctata & Spotted sicklefish & 0.13 & 175 & 17.5 & 50 & 0.35 \\
\hline Scatophagus argus & Spotted Scat & 0.37 & 67.3 & 12.9 & 38 & 0.34 \\
\hline $\begin{array}{l}\text { Sphyraena } \\
\text { sphyraena }\end{array}$ & Baraccuda & 7.73 & 93 & 25.2 & 165 & 0.15 \\
\hline $\begin{array}{l}\text { Carangoides } \\
\text { armatus }\end{array}$ & Trevally & 2.77 & 46.3 & 13.7 & 58 & 0.24 \\
\hline $\begin{array}{l}\text { Carcharhinus } \\
\text { melanopterus }\end{array}$ & Blacktip reef shark & 1.84 & 303.5 & 44.75 & 200 & 0.22 \\
\hline
\end{tabular}




\begin{tabular}{|l|l|c|c|c|c|c|}
\hline Remora remora & Shark sucker & 0.16 & 22.5 & 23.25 & 86.4 & 0.26 \\
\hline Otholites ruber & Tigertooth & 2.64 & 53 & 15.65 & 90 & 0.17 \\
\hline
\end{tabular}

Table 2. shows the composition of demersal fish caught by mini bottom trawl. The composition of demersal fish has as many as 20 species; the pony fish (Leiognathus equulus) and largehead hairtail (Trichiurus lepturus) were the fish that were mostly caught by mini bottom trawl, $31.23 \%$ and $23.52 \%$ respectively. While the lowest catch of mini bottom trawl is spotted sicklefish (Drepane punctata) as much as $0.13 \%$. The longest fish is $65 \mathrm{~cm}$, and the shortest is $2.4 \mathrm{~cm}$. While the heaviest fish is $520 \mathrm{~g}$ and the smallest is $0.3 \mathrm{~g}$. The heaviest average catch is $303.5 \mathrm{~g}$, and the smallest is $8.46 \mathrm{~g}$. The distribution of length of demersal fish caught by mini bottom trawl showed in Figure 5.

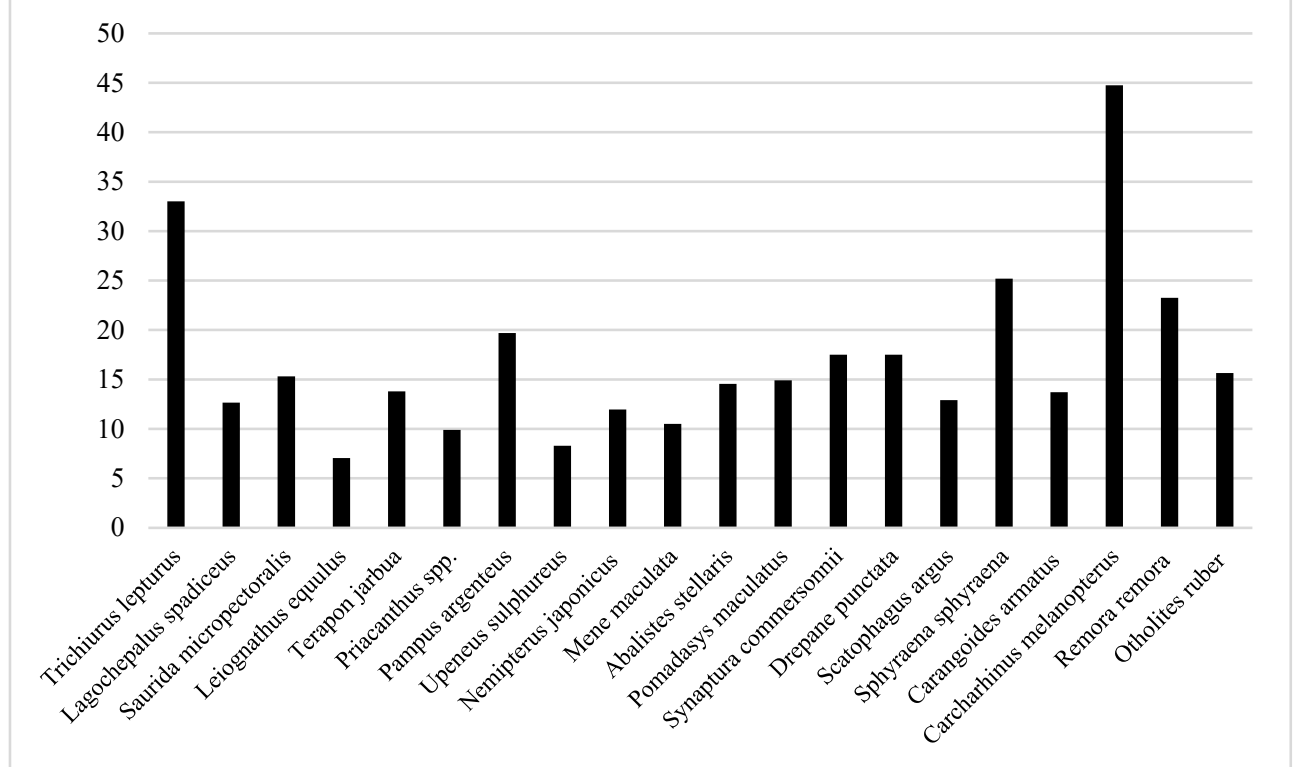

Fig. 5. The distribution of length of demersal fish.

Figure 5 shows the average length of demersal fish caught by mini bottom trawl. The longest demersal fish caught by mini bottom trawl is $44.75 \mathrm{~cm}$, and the shortest is $7.05 \mathrm{~cm}$. The total of mini bottom catches showed in Figure 6.

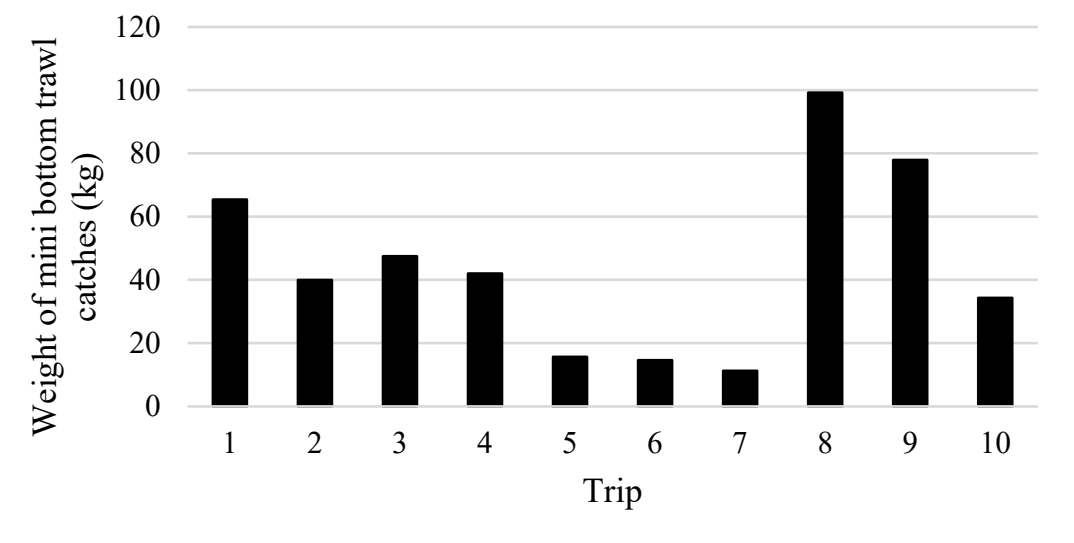

Fig. 6. The total weight of fish caught by mini bottom trawl at the Coast Demak Regency. 
Figure 6 shows the total weight of fish caught mini bottom trawl catches at the Coast Demak Regency for each trip during the study. The maximum weight of fish caught by mini bottom trawl is $99.19 \mathrm{~kg}$, while the minimum is $11.22 \mathrm{~kg}$. The total catches of demersal weight fish showed in Figure 7.

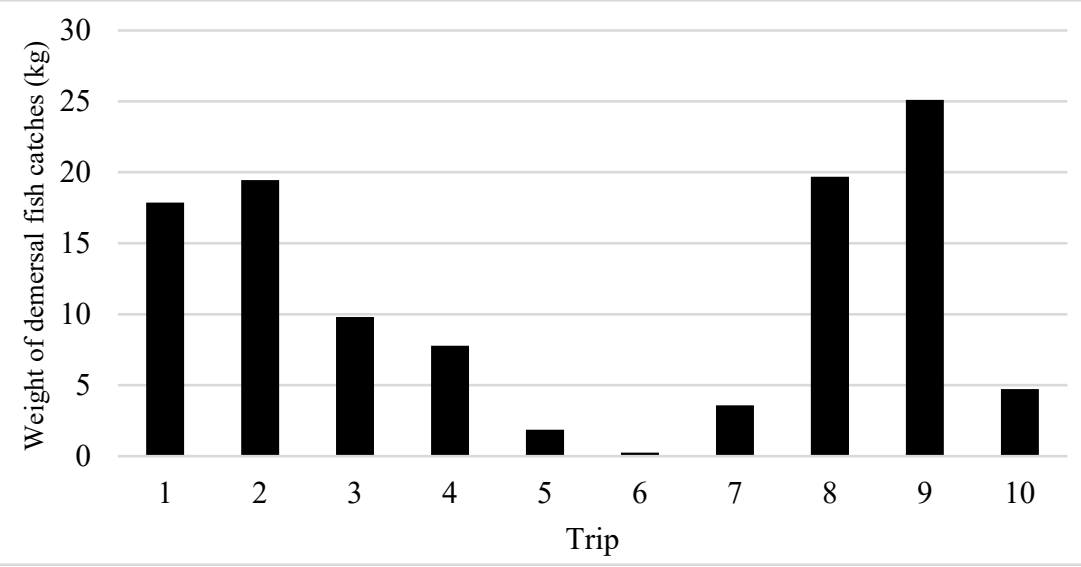

Fig. 7. The total weight of demersal fish catches.

Figure 7 shows the variation of the weight of demersal fish caught by mini bottom trawl during the study. The highest weight of demersal fish was obtained on trip nine, as much as $25 \mathrm{~kg}$, and the lowest was $0.24 \mathrm{~kg}$ on trip six. The Catch per Unit Effort (CPUE) of mini bottom trawl showed in Table 3.

Table 3. The CPUE of mini bottom trawl at the Coast Demak Regency.

\begin{tabular}{|c|c|c|}
\hline Trip & Weight $(\mathrm{kg})$ & CPUE (kg/trip) \\
\hline 1. & 65.42 & 65.42 \\
\hline 2. & 39.95 & 39.95 \\
\hline 3. & 47.47 & 47.47 \\
\hline 4. & 42.01 & 42.01 \\
\hline 5. & 15.65 & 15.65 \\
\hline 6. & 14.63 & 14.63 \\
\hline 7. & 11.22 & 11.22 \\
\hline 8. & 99.19 & 99.19 \\
\hline 9. & 77.88 & 77.88 \\
\hline 10. & 34.27 & 34.27 \\
\hline Total & 447.72 & 447.72 \\
\hline Average & 44.77 & 44.77 \\
\hline
\end{tabular}

Table 3 shows the average weight of the catch of mini bottom trawl is $44.77 \mathrm{~kg}$ and the average catch rate (CPUE) around $44.77 \mathrm{~kg} /$ trip. The highest CPUE was obtained at 99.19 $\mathrm{kg} /$ trip, while the lowest CPUE value was $11.22 \mathrm{~kg} /$ trip.

\section{Discussion}

The catches of mini bottom trawl consisted of 38 species, i.e., 31 demersal and pelagic fish species, four mollusks, and three crustaceans. The distribution of demersal fish catches by 
$23 \%$, pelagic fish (39\%), mollusks (12\%), crustaceans $(4 \%)$, and mixed fish by $22 \%$. The fish captured dominated by ponyfish (Leiognathus equulus) as much as $31.23 \%$ and largehead hairtail (Trichiurus lepturus) of $23.52 \%$. In contrast, other demersal fish species consist of moonfish, silver pomfret, spotted sicklefish, blacktip reef shark. As a comparison, at the PPI Tambak Lorok, Semarang, mini bottom trawl caught four groups of organisms consisting of crustaceans, mollusks, fish, and echinoderms [6]. The organisms with the highest percentage were fish as much as $32 \%$, while in TPI Asemdoyong Pemalang the catch of mini bottom trawl was dominated by lizardfish and ponyfish, $16 \%$ and $9.1 \%$ respectively [7]. The difference in dominance results might be caused by the season and fishing location.

The average weight of the catch of mini bottom trawl on Coast Demak is $44.77 \mathrm{~kg}$ with a CPUE value of $44.77 \mathrm{~kg} /$ trip. The higher result of the use of mini bottom trawl was reported in Pemalang Waters (123.14 kg/trip) [7]. This difference might be caused by fishing ground characteristics and natural factors like weather, wind, and wave action. In the west season, some areas of the North Java Sea experience the rainy season Hence, fishermen cannot go to sea because of strong winds and waves [8]. Technical factors include the addition of machine tools and damage of the fishing gear when catching and capturing the location. Fishermen also added engines from 3 to 4 to increase the speed of the boat. The addition of the machine is also motivated by the competition between mini bottom trawl fishermen. The most significant factors influencing the catch of mini bottom trawl include cod-end length, engine strength, and warp length [9].

The distribution of weight and length of catches of demersal fish was very diverse. The results showed that $95.23 \%$ of fish species caught were still below the maximum length (Lmax). Research from [10], the catches of 74 ponyfish were worth catching, and 7228 were undersized fish, the catch of 12 large head hairtail was worth catching, and 1419 were undersized fish. The weight ranges from 0.3 to $520 \mathrm{~g}$ and is more than $98 \%$ sized $0.3-80 \mathrm{~g}$. Based on the research results, the mini bottom trawl obtained as many as 38 species with various sizes from small to large. This number of species and various sizes of fish caught by mini bottom trawl lead this fishing gear was classified as very low selectivity because it captures bycatch highly and damages the habitat [11].

According to the PERMEN of Marine Affair and Fisheries Republic of Indonesia No. 59 of 2020, the use of mini bottom trawl in the FMA 712 is allowed on condition with a specific level of selectivity and capacity, that is has a head rope length $\leq 40 \mathrm{~m}$, a warp length $\leq 300 \mathrm{~m}$, boat size $>5 \mathrm{GT}$, and 1 -inch mesh size. The mini bottom trawl used to catch fish at Coast Demak Regency generally has a head rope length of $9 \mathrm{~m}$, a warp length of $125 \mathrm{~m}$, and a boat size of $5 \mathrm{GT}$; following MOMAF regulations, but it has a smaller mesh size of cod-end, i.e., 0.5-1 inch. The large number of small fish caught of mini bottom trawl at the Coast of Demak Regency might be caused by the smaller mesh size of the cod-end (0.5-1 inch). Using a smaller cod-end for their mini bottom trawl means not following the regulations, decreasing demersal fish resources. The differences in mesh size will affect the size of the fish caught by fishing gear. The larger mesh size causes much easier for the fish to escape; meanwhile, the smaller mesh size causes much easier for the fish to be trapped [12].

Shrimp is the main target of mini bottom trawl, whereas the bycatch is the demersal and pelagic fish, mollusks, and other small fish. This research showed that mini bottom trawl is only caught $4 \%$ of the main target, whereas the non-target is $96 \%$. A large number of bycatch can threaten the extinction of biota and impact the natural regeneration of the ecosystem. Fishing gear (API) that destroys resources is prohibited from operating in all fishing lanes (KEPMEN 59/2020). Two main actions used to reduce bycatch are input and output control and management technique such as limitation applied in the number of boat and fishing gear and technique including net mesh size and selective panel installation in the fishing gear [1314]. 
The effects of bottom trawls are generally similar to those other types of disturbance [1517], including significant reductions in species diversity and populations, as well as reduced productivity of the benthos [17-19]. Physical effects on the seafloor may include reduced stability, structural complexity, altered forms, and biogeochemical changes [15-17].

\section{Conclusion}

The composition of catch using mini bottom trawl as many as 38 species consists of 31 fish, four mollusks, and three crustaceans. The catches of mini bottom trawl consist of demersal fish $(23 \%)$, pelagic fish (39\%), mollusk (12\%), crustacea (4\%), and mixed fish $(22 \%)$. The pony fish (Leiognathus equulus) and large head hairtail (Trichiurus lepturus) are the fish that are mostly caught by mini bottom trawl (31.23\% and $23.52 \%$ ). More than $95 \%$ of fish caught by mini bottom trawl were categorized as small compared to the maximum attainable length (L-max). The average CPUE of the mini bottom trawl is around $44.77 \mathrm{~kg} /$ trip.

\section{References}

1. N. N. Wiadnyana, Badrudin, Aisyah, J. Lit. Perikan. Ind, 16, 275-283 (2010)

2. D.H. Mayu, Kurniawan, A. Febrianto, IJoCF. 2, 30-41 (2018)

3. A. Suhariyanto, F. Rachman, E. Setyobudi, R.Y. Setiawan, N. Alfiatunnisa, S.S. Djasmani, E3S Web of Conf., 147, 1-9 (2020)

4. H. Manadiyanto, H. Latif, S. Iriandi, Status and Utilization of Penaeid Shrimp After Tiger Trawl in the Waters of Java Sea (Jakarta, BPPL, 2000)

5. H. Saanin, Taksonomi dan Kunci Taksonomi Ikan (Bina Cipta, Jakarta, 1984)

6. E. Septiana, S.W. Saputra, A. Ghofar, IJFST, 14, 100-105 (2019)

7. T. Ernawati, B. Sumiono, J. Lit. Perikan. Ind. 16, 267-274 (2010)

8. J. Widodo, Suadi, Marine Fisheries Resource Management (Yogyakarta, UGM Press, 2006)

9. B. I. Prisantoso, L. Sadiyah, K.Susanto, J. Lit. Perikan. Ind. 16, 93-105 (2010)

10. H.A. Nugroho, A. Rosyid, A.D.P. Fitri, JRUMT, 4, 11 (2015)

11. FAO, Code of conduct for responsible fisheries, 1st Ed (FAO, Rome, 1995)

12. F. Mahendra, A. D. P Fitri, Asriyanto, JFRUMT, 4, 1-11 (2015)

13. M. Lundin, Size Selection of Fish in The Trap Fisheries of The Baltic and Bothnian Seas (Sweden, Swedish Univ of Agri Sci, 2014)

14. N. Alfiatunnisa, F. Rachman, E. Setyobudi, S.S. Djasmani, IOP Conf. Ser. Earth and Environ. Sci., 404, 1-9 (2020)

15. L.M. Mayer, D.F Schick, R.H. Findlay, MER, 31, 249-261 (1999)

16. P. Schwinghamer, D.C Gordon, T.W. Rowel, J. Prena, D.L. McKeown, G. Sonnichsen, J. Y. Guignes, Conv. Bio. 12. 6. 1215-1222 (1998)

17. R. A. McCnnaughey, S.E. Syrjala, ICES J. Mar. Sci, 71, 2469-2483 (2014).

18. S. Jennings, M.J. Kaiser, Adv. Mar. Bio, 34, 201-250 (1998)

19. Pw. Barnes, J.P. Thomas, Benthic Habitats and the Effects of Fishing (Bethesda, Maryland Amer. Fish. Soc, 2005). 